\title{
PENGARUH INOVASI TERHADAP KINERJA PERUSAHAAN
}

\author{
Megawati Yuliana Putri 130119016 \\ Sinta Alisa Qortrun Nanda 130119023 \\ Tri Lailatul Humairoh $\quad 130120059$
}

FAKULTAS BISNIS DAN EKONOMIKA

UNIVERSITAS SURABAYA

\begin{abstract}
Abstrak
Studi ini menyelidiki bagaimana pengaruh inovasi terhadap kegiatan perusahaan. Hasil pembahasan kami menunjukkan bahwa inovasi berpengaruh positif terhadap kinerja perusahaan yang didukung dengan banyaknya hasil penelitian dari para analis. Inovasi mendorong sebuah perusahaan untuk meningkatkan kinerjanya agar dapat bersaing dengan kompetitor.
\end{abstract}

Kata Kunci: Inovasi, Inovasi Terbuka, Eco-inovasi, Kinerja Perusahaan

\section{Tinjauan Literatur}

Konsep kinerja perusahaan adalah suatu proses yang digunakan oleh perusahaan untuk mencapai misi dan visi. Sementara bisnis dengan sumber keuangan yang terbatas dan teknologi yang sudah ketinggalan penting diperhatikan untuk mengubah kinerja perusahaan agar mendorong pengetahuan inovasi dan lingkungan kerja yang positif. Dalam jurnal tersebut untuk menentukan kapasitas perusahaan dengan mengendalikan harga pasar atas marjinalnya. namun untuk bisnis yang berskala kecil mendapatkan keuntungan dari pesaing. Kinerja perusahaan adalah konsep multidimensional yang bersifat departemen seperti berkaitan dengan produksi, keuangan, pemasaran, atau konsekuensi yang bersangkutan dengan pertumbuhan dan laba (Pratono et al., 2016).

Inovasi terbuka (open innovation) merupakan proses pengembangan produk yang mencakup sumber daya terbuka dan pendekatan partisipatif yang terdesentralisasi dan terdistribusi. Pengembangan produk merujuk pada kemampuan perusahaan untuk berinovasi dengan menawarkan layanan dan produk baru bertujuan untuk memenuhi kebutuhan konsumen (Murray et al., 2011). Inovasi mencakup berbagai kegiatan, dari membangun ide, implementasi, hingga pembauran. Studi lain telah mengidentifikasi konsep inovasi serupa seperti menghasilkan ide, pengembangan inovasi, dan difusi inovasi (Pratono et al., 2018).

Banyak perusahaan terlibat inovasi grassroots dalam upaya meningkatkan budaya inovasi yang kuat. Inovasi grassroots merupakan bentuk pengembangan inovasi oleh setiap anggota perusahaan tanpa memandang jabatan atau usia (Stremersch et al., 2021). Selain itu, terdapat salah satu jenis inovasi yang dapat diterapkan perusahaan, yaitu eco-inovasi. Eco- 
inovasi adalah upaya baru dalam meningkatkan solusi ramah lingkungan dan penghijauan secara berkelanjutan yang merupakan konsep penting bagi perusahaan manufaktur karena prospek inovasinya yang bermanfaat bagi lingkungan (Janahi et al., 2021).

\section{Kesimpulan}

Inovasi adalah sebuah mekanisme dalam suatu perusahaan untuk beradaptasi dalam lingkungan yang dinamis. Perusahaan dituntut dapat melahirkan nilai, ide - ide baru, produk berkualitas, dan menawarkan produk inovatif. Inovasi merupakan sarana dalam membangun dan mengembangkan kinerja perusahaan melalui pembaruan teknologi, produk dan berbagai layanan, serta pengembangan target pasar. Oleh karena itu, semakin tinggi tingkat inovasi yang dilakukan, maka kinerja perusahaan juga semakin tinggi. Inovasi menjadi salah satu strategi untuk mengembangkan perusahaan agar tetap berjalan. Perusahaan dapat tumbuh lebih cepat daripada yang lain karena adanya sebuah inovasi (Lee et al., 2019). Dalam lingkungan bisnis yang ketat dan kompetitif, perusahaan harus bersaing dengan perusahaan lain agar dapat memimpin pasar dengan dibantu oleh peningkatan teknologi berkelanjutan dan pengembangan model bisnis yang inovatif. Pengaruh inovasi pada kinerja perusahaan dalam sebuah bisnis untuk membangun perusahaan sebagai penggerak perekonomian berkelanjutan, dinamis, kompetitif, dan berpengetahuan. Salah satu hubungan positif yang diperoleh dari adanya inovasi dapat menciptakan permintaan pasar dan membuat perusahaan memperoleh keuntungan yang relatif tinggi. Dari banyaknya analisis pengaruh inovasi terhadap kinerja perusahaan, dapat disimpulkan bahwa hampir seluruhnya inovasi secara positif dan signifikan mempengaruhi kinerja perusahaan (Ebersberger et al., 2021). 


\section{Referensi}

Atalay, M., Anafarta., \& Sarvan, F. (2013). The relationship between innovation and firm performance: An empirical evidence from Turkish automotive supplier industry. Procedia -Social and Behavioral Sciences 75, 226-235

Ebersberger, B., Herstad, S. J., \& Nordli, A. (2021). Hospitality innovation strategies: Robustness analysis of paths to firm performance. Tourism Management, 85, 104310. https://doi.org/10.1016/j.tourman.2021.104310

Janahi, N. A., Durugbo, C. M., \& Al-Jayyousi, O. R. (2021). Eco-innovation strategy in manufacturing: A systematic review. Cleaner Engineering and Technology, 100343. https://doi.org/10.1016/j.clet.2021.100343

Lee, R., Lee, J.-H., \& Garrett, T. C. (2019). Synergy effects of innovation on firm performance. Journal of Business Research, 99, 507-515. https://doi.org/10.1016/i.jbusres.2017.08.032

Pratono, A. H., Saputra, R. S., \& Pudjibudojo, J. K. (2016). The Social Capital and Firm Performance: Evidence from Indonesia small businesses. International Journal of Economics and Financial 6 (S7), 47-50.

Pratono, A. H. (2018). Network structure and open innovation: the role of trust in product development. International Journal of Business Innovation and Research, 15(1), 44-61.

Pratono, A. H., Marciano, D., \& Jeong, B. G. (2018). Internationalization of Social Enterprise: Scaling Up the Social Innovation in Indonesia. KnE Social Sciences.

Stremersch, S., Camacho, N., Keko, E., \& Wuyts, S. (2021). Grassroots innovation success: The role of self-determination and leadership style. International Journal of Research in Marketing. https://doi.org/10.1016/j.ijresmar.2021.10.003 